\title{
Fatty Acid Synthesis in the Regenerating Liver of the Rat
}

\author{
By CHRISTOPHER D. GOVE* AND DOUGLAS A. HEMS* \\ Department of Biochemistry, Imperial College of Science and Technology, \\ London SW7 2AZ, U.K.
}

(Received 20 May 1977)

\begin{abstract}
1. Synthesis de novo of fatty acids in the rat liver, measured per $\mathrm{g}$ wet wt. of tissue, was increased by a factor of about two, between 1 and 4 days after partial hepatectomy, compared with rates in sham-operated control rat livers. 2 . There were no associated changes in the rates of liver cholesterol synthesis or of adipose-tissue fatty acid synthesis in rats after partial hepatectomy, compared with rates in sham-operated rats. 3. In regenerating livers, perfused under three different conditions, there was no alteration in the capacity for fatty acid synthesis compared with that of control rats. 4 . The increased synthesis of fatty acids in regenerating liver was associated with insignificant increases in plasma concentrations of triacylglycerols and free fatty acids, with a decrease in content of liver glycogen, and with no change in hepatic activity of acetyl-CoA carboxylase. 5 . The accelerated rate of synthesis of fatty acids in regenerating liver appears not to be due to any intrinsic alteration in hepatic capacity for fatty acid synthesis, but it may be caused by the continuous action on liver of unidentified circulating factors.
\end{abstract}

During regeneration of the liver, there is a requirement for synthesis of new tissue components. Although it is well established that protein synthesis is increased during the period of re-growth, the details of the reconstitution of lipid components (membranes, fat-droplets, lipoproteins) are not fully documented. There is usually an increased content of hepatic fat during regeneration; the extra lipid consists of triacylglycerols (Glende \& Morgan, 1968), whereas phospholipid deposition (with the exception of cardiolipin) exactly keeps pace with the overall growth rate (Glende \& Morgan, 1968; Tata, 1970; Fex, 1970b; Bergelson et al., 1974; Fex \& Thorzell, 1975). Triacylglycerol synthesis, at least from preformed fatty acids, is increased after resection of part of the liver, as may be demonstrated with labelled fatty acids (Fex \& Olivecrona, 1968a; Olivecrona \& Fex, 1970; Fex, 1970a) or glycerol (Olivecrona \& Fex, 1970). This synthesis of extra triacylglycerols (per unit mass of tissue), which occurs in the absence of any extra phospholipid synthesis (Fex, 1970b; Girard et al., 1971), may be partly a result of increased activity of phosphatidate phosphohydrolase (Mangiapane et al., 1973). Rates of export of triacylglycerol are maintained during re-growth, i.e. the liver increases the rate per $\mathbf{g}$ of tissue, to compensate for the lost liver (Fex \& Olivecrona, 1968a,b; Delahunty \& Rubinstein, 1970).

The above processes of glyceride metabolism could be sustained by free fatty acids derived from

* Present address: Department of Biochemistry, St. George's Hospital Medical School, Cranmer Terrace, London SW17 ORE, U.K. blood. An open question, however, is whether the synthesis de novo of long-chain fatty acids in the liver is increased during regeneration. For example, there have been studies of fatty acid synthesis de novo demonstrating that synthesis from $\left[{ }^{14} \mathrm{C}\right]$ acetate in slices of regenerating liver is increased by about 3 days after hepatectomy (Takeuchi et al., 1976) and yet injected substrates appear to be converted less rapidly into fatty acids in regenerating liver of intact rats (Bartsch \& Gerber, 1966; Neville et al., 1970).

In the experiments described here, the question of synthesis de novo of fatty acid in the liver during regeneration has been investigated by measuring ${ }^{3} \mathrm{H}$ incorporation from ${ }^{3} \mathrm{H}_{2} \mathrm{O}$ into fatty acids. This technique gives a quantitative measure of the total rate of conversion of acetyl residues into fatty acid (Lowenstein, 1971; Hems et al., 1975). The results show that synthesis is increased during the phase of most active liver growth. Measurements of liver glycogen and of synthesis of cholesterol in liver and fatty acids in adipose tissue are also presented.

\section{Materials and Methods}

\section{Animals}

Male rats of the Sprague-Dawley strain were fed on a standard Thompson's diet (Oxoid, London S.E.1, U.K.). Partial hepatectomy of standard type (removal of both major sublobes of the left lobe, comprising removal of two-thirds of the liver), or sham operation, was carried out under mediumdepth anaesthesia with air/diethyl ether, through a sagittal midline skin incision and a longitudinal 
incision of the muscle layer. Skin was sutured with clips. In the standard procedure, rats were fully conscious within $10 \mathrm{~min}$ after the operation. We formed the impression that a faultless procedure is of relevance to subsequent events in the animals; in particular, rapid resumption of satisfactory food intake can condition metabolic processes, and may minimize the extent and duration of the increased hepatic fat deposition.

\section{Chemicals}

Solvents and chemicals were of the highest grade available from Fisons (Loughborough, Leics., U.K.), Hopkin and Williams (Romford, Essex, U.K.) or BDH Chemicals (Poole, Dorset, U.K.). Alcohols were from James Burrough (London S.E.11, U.K.). Standard lipids, acetyl-CoA and dithioerythritol were from Sigma (London) Chemical Co. (London S.W.6, U.K.). Labelled compounds were from The Radiochemical Centre (Amersham, Bucks., U.K.). Enzymes and substrates for glycerol determination were from Boehringer Corp. (London) Ltd. (London W.5. U.K.). Bovine serum albumin (fraction V) was from Miles Laboratories (Stoke Poges, Slough, Berks., U.K.).

\section{Experimental}

Unless indicated to the contrary, animals received ${ }^{3} \mathrm{H}_{2} \mathrm{O}(10-20 \mathrm{mCi} / \mathrm{rat})$ and in some experiments a trace dose $(12 \mu \mathrm{Ci})$ of $\left[\mathrm{U}-{ }^{14} \mathrm{C}\right]$ glucose $(3 \mathrm{mCi} / \mathrm{mmol})$ intraperitoneally between 10.00 and $12.00 \mathrm{~h}$, in a volume of $0.2 \mathrm{ml}$. Tissues were analysed after $1 \mathrm{~h}$ for the ${ }^{3} \mathrm{H}$ or ${ }^{14} \mathrm{C}$ content of acylglycerols, fatty acids or cholesterol (Salmon et al., 1974; Hems et al., 1975). Incorporation of ${ }^{3} \mathrm{H}$ into lipids is linear with time over $1 \mathrm{~h}$ (Lowenstein, 1971, so that this technique provides a valid measure of the rate of fatty acid synthesis. Liver glycogen (Salmon et al., 1974) and total fat content (Salmon \& Hems, 1973) were measured. Blood was rapidly removed by cardiac puncture from the stunned rats, and serum was prepared for analysis of free fatty acids and total triacylglycerol (Salmon \& Hems, 1973). Radioactivity was measured in fatty acid classes separated by degree of saturation (Salmon et al., 1974). Livers of red rats were perfused as previously described (Kirk et al., 1976).

\section{Assay of acetyl-CoA carboxylase (EC 6.4.1.2) in liver}

Acetyl-CoA carboxylase activity was assayed by the method of Halestrap \& Denton (1973), with minor modifications. Liver was freeze-clamped immediately on sampling, in liquid $\mathbf{N}_{2}$. Frozen pieces were weighed and homogenized at $4^{\circ} \mathrm{C}$ in $9 \mathrm{vol}$. of $0.1 \mathrm{M}$ of potassium phosphate, $\mathrm{pH7.4}$, containing $0.5 \mathrm{mM}$-EDTA, $5 \mathrm{mg}$ of bovine serum albumin [made free of fatty acids by the procedure of Chen (1967) $] / \mathrm{ml}$ and $2 \mathrm{mM}$-dithioerythritol. Homogenates were centrifuged at $38000 \mathrm{~g}$ for $60 \mathrm{~min}$ at $4^{\circ} \mathrm{C}$. After removal of the fat-cake the supernatant was transferred (at $4^{\circ} \mathrm{C}$ ) to a clean plastic tube. Assays were started within $1 \mathrm{~h}$. Frozen liver was never stored for longer than 3 days. Separate experiments showed that a delay of up to $2 \mathrm{~h}$ (at $4^{\circ} \mathrm{C}$ ), or of up to 3 days (frozen at $-20^{\circ} \mathrm{C}$ ), made no significant difference to the measured enzyme activities (or to the ratio of initial and total activities).

Supernatants were divided into two parts. One was assayed untreated (initial activity). The other was treated for $30 \mathrm{~min}$ at $37^{\circ} \mathrm{C}$ in $15 \mathrm{~mm}-\mathrm{MgCl}_{2} / 10 \mathrm{~mm}$ potassium citrate, to bring about activation of the enzyme (total activity.) These concentrations were obtained by adding $10 \mu \mathrm{l}$ of stock solutions $(1 \mathrm{M}$ and $1.5 \mathrm{M}$ respectively) $/ \mathrm{ml}$.

Enzyme activity was assayed at $37^{\circ} \mathrm{C}$ in sealed tubes with a small gas space by measuring incorporation of ${ }^{14} \mathrm{C}$ from $\mathrm{KH}^{14} \mathrm{CO}_{3}$ into malonyl-CoA. The reaction mixture $(0.45 \mathrm{ml}, \mathrm{pH} 7.4)$ contained $100 \mathrm{~mm}$ Tris/ $\mathrm{HCl}, 10 \mathrm{~mm}-\mathrm{MgCl}_{2}, 10 \mathrm{~mm}$-potassium citrate, 2 mM-dithioerythritol, bovine serum albumin (fatty acid-free, $5 \mathrm{mg} / \mathrm{ml}$ ), $0.5 \mathrm{~mm}$-EDTA, $5 \mathrm{~mm}$-ATP, $0.15 \mathrm{~mm}$-acetyl-CoA and $15 \mathrm{~mm}-\mathrm{KH}^{14} \mathrm{CO}_{3}$ (about $1 \mu \mathrm{Ci} / \mu \mathrm{mol})$. The citrate was present to systematize the concentration of this potential modifier in view of a report that it may activate at least one form of the enzyme (Carlson \& Kim, 1974); omission of citrate decreased the initial activity by about $30 \%$ in normal or regenerating liver. The reaction, started with $50 \mu \mathrm{l}$ of tissue supernatant, lasted $3 \mathrm{~min}$ at $37^{\circ} \mathrm{C}$, and was terminated with $0.2 \mathrm{ml}$ of $5 \mathrm{M}-\mathrm{HCl}$. After centrifugation $(500 \mathrm{~g}$ for $15 \mathrm{~min}), 0.5 \mathrm{ml}$ of supernatant was dried, the residue taken up in $0.1 \mathrm{ml}$ of water and ${ }^{14} \mathrm{C}$ was determined. Blanks lacked acetyl-CoA, and non-volatile ${ }^{14} \mathrm{C}$ (less than $20 \%$ of the lowest enzyme activities) was subtracted from sample values.

\section{Calculation of results}

The total amount of newly synthesized fatty acid in tissues was calculated from the incorporation of ${ }^{3} \mathrm{H}$ from ${ }^{3} \mathrm{H}_{2} \mathrm{O}$, and is expressed as mol of $\mathrm{C}_{2}$ units converted into fatty acids, taking a factor of 2.4 as the discrimination against ${ }^{3} \mathrm{H}$ compared with ${ }^{1} \mathbf{H}$ (Windmueller \& Spaeth, 1966; Lowenstein, 1971; Salmon et al., 1974). Thus one acetyl residue would carry 1.7 atoms of ' $H$ ' (calculated in the standard manner, i.e. as if there were no isotope effect) into product fatty acid. This calculation provides a minimum estimate of fatty acid synthesis, as mixing of ${ }^{3} \mathrm{H}$ in all tissue pools is presumed. Calculation of results as $\mathbf{C}_{2}$ units involves no presumptions about chain length of product fatty acids.

Cholesterol synthesis has been calculated by invoking the same discrimination factor; cholesterol contains less than $4 \mathrm{H}$ atoms per $\mathrm{C}_{2}$ unit, so an acetyl residue incorporated into cholesterol carries with it 
1.4 atoms of ' $\mathrm{H}$ ' (calculated as if there were no isotope effect).

\section{Results}

\section{Characteristics of rats after partial hepatectomy}

The procedure of removal of two-thirds of the liver, involving laparotomy and its associated stresses, produces non-specific effects on food intake and growth, and thus on liver weight and function. These effects can best be revealed in animals that undergo a sham operation. Such control rats were used throughout the present study. In both hepatectomized and sham-operated rats, there was a transient fall in food intake and a loss of weight (Table 1). This was slightly more marked in partially hepatectomized rats, but they were eating and growing normally by day 4 after hepatectomy (Table 1). As would be expected during partial food-deprivation, liver weights fell slightly on the first day after sham operation (Table 2). In hepatectomized rats, the liver had regained much of its lost weight by day 4 after operation (Table 2 ).
Synthesis de novo of liver fatty acids after partial hepatectomy

The synthesis de novo of fatty acids was followed with ${ }^{3} \mathrm{H}_{2} \mathrm{O}$ as a function of time after partial hepatectomy. During the phase of rapid re-growth (1-3 days after hepatectomy), hepatic fatty acid synthesis (per $\mathrm{g}$ of fresh liver) was increased, compared with rates in either sham-operated control rats or untreated animals (Fig. 1). Lipogenesis was also increased when expressed per whole liver in regenerating liver compared with control livers (Fig. 1.)

\section{Fatty liver after partial hepatectomy}

It is well established that the regenerating liver usually accumulates a small amount of extra fat. In our series of animals this was true for the first 2 days after partial hepatectomy, in comparison with shamoperated controls (Table 2). The sham-operated rats showed a relative decline in fat content during the first 2 post-operative days (Table 2), perhaps as a result of partial mobilization of liver fat in response to food-deprivation.

Table 1. Weights and food intakes of rats after partial hepatectomy

Rats underwent partial hepatectomy or sham operation, and subsequent changes in weight (compared with initial postoperative weight) and food intake were recorded. In untreated rats, the average weight was $202 \mathrm{~g}$ at the age when other rats were operated, and $237 \mathrm{~g}$ after 6 days, and the average food intake was $25 \mathrm{~g} / 24 \mathrm{~h}$ per rat. Other details are in the text. Results are means \pm S.E.M. for the numbers of observations given in parentheses. ${ }^{*} P<0.01$, compared with the shamoperated value.

Time after
partial
hepatectomy
(days)

1
2
3
4
5
6

Cumulative change in body weight (g/day)

$\begin{array}{cc}\begin{array}{c}\text { Partial } \\ \text { hepatectomy }\end{array} & \begin{array}{c}\text { Sham } \\ \text { operation }\end{array} \\ -8.8 \pm 0.7(50)^{*} & -5.0 \pm 0.7(49) \\ -2.8 \pm 0.8(49)^{*} & +3.0 \pm 0.9(50) \\ +0.5 \pm 1.4(34)^{*} & +8.1 \pm 0.8(32) \\ +7.4 \pm 2.4(18) & +9.2 \pm 2.2(13) \\ +8.3 \pm 5.6(3) & +15.8 \pm 4.0(6) \\ +22.2 \pm 2.0(8) & +27.3 \pm 3.5(10)\end{array}$

Food intake (g/24h per rat)

$\begin{array}{cc}\begin{array}{c}\text { Partial } \\ \text { hepatectomy }\end{array} & \begin{array}{c}\text { Sham } \\ \text { operation }\end{array} \\ 12 \pm 1(8)^{*} & 17 \pm 1(8) \\ 19 \pm 3(5) & 21 \pm 2(5) \\ 27 \pm 6(3) & 24 \pm 2(6) \\ 21 \pm 3(3) & 23 \pm 2(4) \\ 22(2) & 24 \pm 2(3) \\ 24(2) & 26 \pm 2(3)\end{array}$

Table 2. Weights and lipid contents of livers after partial hepatectomy

At various times after partial hepatectomy or sham operation, livers were weighed, and fat-content was determined. Liver weight was about $10 \mathrm{~g}$ in untreated rats (fed ad lib.) and about $3.5 \mathrm{~g}$ immediately after partial hepatectomy; the hepatic fat content in untreated rats was $55 \pm 3 \mathrm{mg} / \mathrm{g}$. Results are means \pm S.E.M. for the numbers of measurements given in parentheses. ${ }^{*} P<0.01$ compared with the sham-operated value.

\begin{tabular}{ccc}
$\begin{array}{c}\text { Time after } \\
\text { partial } \\
\text { hepatectomy } \\
\text { (days) }\end{array}$ & \multicolumn{1}{c}{$\begin{array}{c}\text { Partial } \\
\text { hepatectomy }\end{array}$} & $\begin{array}{c}\text { Sham } \\
\text { operation }\end{array}$ \\
1 & $4.3 \pm 0.5(4)^{*}$ & $8.4 \pm 0.3(4)$ \\
2 & $5.9 \pm 0.3(7)^{*}$ & $9.5 \pm 0.3(9)$ \\
3 & $6.3 \pm 0.2(6)^{*}$ & $8.2 \pm 0.4(9)$ \\
4 & $7.7 \pm 0.5(6)$ & $9.0 \pm 0.5(5)$
\end{tabular}

Liver lipid content $(\mathrm{mg} / \mathrm{g})$

\begin{tabular}{cc}
\hline $\begin{array}{c}\text { Partial } \\
\text { hepatectomy }\end{array}$ & $\begin{array}{c}\text { Sham } \\
\text { operation }\end{array}$ \\
$71 \pm 16(5)$ & $46 \pm 2(4)$ \\
$55 \pm 8(8)$ & $39 \pm 2(6)$ \\
$58 \pm 11(6)$ & $56 \pm 7(6)$ \\
$59 \pm 4(6)$ & $55 \pm 3(5)$
\end{tabular}

Vol. 170 


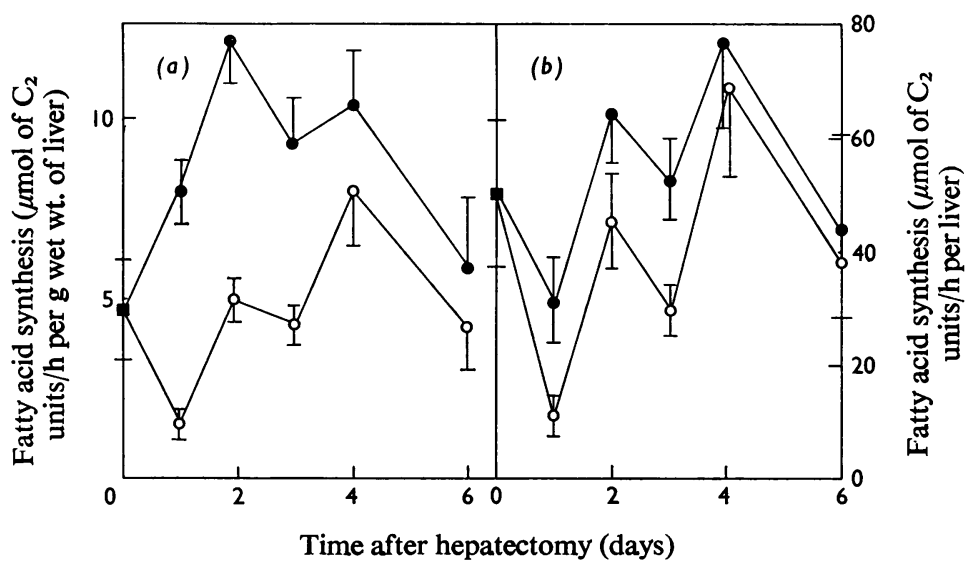

Fig. 1. Fatty acid synthesis in rat liver after partial hepatectomy

At various times after partial hepatectomy $(\bullet)$ or sham operation $(O)$, rats were injected with ${ }^{3} \mathrm{H}_{2} \mathrm{O}$. Liver fatty acids were analysed for ${ }^{3} \mathrm{H}$ after $1 \mathrm{~h}$. Operations and experiments were carried out between 10.00 and $13.00 \mathrm{~h}$. The zero-time value ( $\boldsymbol{\square})$ is given for non-operated rats. Fatty acid synthesis is expressed as $\mu$ mol of $\mathrm{C}_{2}$ units/h, either $(a)$ per $\mathrm{g}$ of fresh liver, or $(b)$ per whole liver. Other details are given in the text. Results are means \pm S.E.M. for four to six observations, except at 2 days post-operatively, where there were 11 hepatectomized and 7 sham-operated rats. The rate of synthesis in regenerating liver (per $\mathbf{g}$ ) is significantly different from that in controls, after 1,2 or 3 days $(P<0.01)$.

If the increased synthesis de novo of fatty acids is of major significance during regeneration, one might expect a relative increase in the major products of synthesis, i.e. palmitate, stearate and oleate. Therefore the composition of hepatic glycerides was analysed, 2 days after hepatectomy, by quantitative g.l.c. (Salmon \& Hems, 1976). The results confirmed that most of the extra fatty acid in regenerating liver (see Table 2) was located in triacylglycerols. The biggest proportional increase was in the hepatic content of triacylglycerol octadecenoates, which was $12.4 \pm 1.7$ (s.E.M.) (3) $\mu \mathrm{mol} / \mathrm{g}$ of fresh liver after partial hepatectomy, and $5.5 \pm 0.6(3)$ in sham-operated rat liver. This increase (in the regenerating liver compared with controls; $P<0.02$ ) was in general agreement with the results of Glende \& Morgan (1968), and is explicable by the influx to liver of fatty acids from plasma, as well as by the increased rate of synthesis de novo.

\section{Synthesis de novo of unsaturated fatty acids in liver} after partial hepatectomy

In view of the established parallelism between processes of lipogenesis and desaturation (Gellhorn $\&$ Benjamin, 1966), the synthesis of unsaturated acids was followed with ${ }^{3} \mathrm{H}_{2} \mathrm{O}$ in the regenerating liver (Table 3). The incorporation of ${ }^{3} \mathrm{H}$ into all fractions was increased after hepatectomy, to approximately the same extent as was observed in the total fatty acid fraction. Thus there was not a specific increase in the

Table 3. Synthesis of unsaturated fatty acids in the liver after partial hepatectomy

At 2 days after partial hepatectomy, or sham operation, rats were injected (intravenously under light ether anaesthesia) with ${ }^{3} \mathrm{H}_{2} \mathrm{O}$. After $100 \mathrm{~min}$, fatty acids from the liver were separated according to degree of saturation, by argentation t.l.c., and the ${ }^{3} \mathbf{H}$ content was determined. Other details are in the text. Results are means \pm S.E.M. of five measurements.

Fatty acid synthesis ( $\mu$ mol of $C_{2}$ units/h per $\mathrm{g}$ fresh wt. of liver)

Fatty acid fraction

Total

Saturated

Monoenoic

Dienoic

Polyenoic

$\begin{array}{cc}\begin{array}{c}\text { Partial } \\ \text { hepatectomy }\end{array} & \begin{array}{c}\text { Sham } \\ \text { operation }\end{array} \\ 9.76 \pm 2.96 & 3.87 \pm 0.35 \\ 6.37 \pm 2.10 & 2.46 \pm 0.26 \\ 1.59 \pm 0.77 & 0.39 \pm 0.05 \\ 0.30 \pm 0.08 & 0.17 \pm 0.35 \\ 1.50 \pm 0.14 & 0.85 \pm 0.08\end{array}$

synthesis de novo of any particular class of fatty acids in the regenerating liver. The incorporation of label into di- and poly-enoic fatty acids was increased after partial hepatectomy, suggesting that elongation of pre-existing essential fatty acids was enhanced in parallel with the overall increase in synthesis rates. On general grounds this would be expected to maintain the pattern of fatty acids produced during the period of accelerated growth. 
Table 4. Synthesis of fatty acids in adipose tissue and of liver cholesterol, after partial hepatectomy In some of the rats described in Tables 1-3, the synthesis of liver cholesterol and epididymal-adipose-tissue fatty acids was followed by using ${ }^{3} \mathrm{H}_{2} \mathrm{O}$. Rats also received a trace dose of $\left[\mathrm{U}-{ }^{14} \mathrm{C}\right]$ glucose. The ratio $\left[{ }^{14} \mathrm{C} /{ }^{3} \mathrm{H}\right.$ in adipose-tissue fatty acid (in d.p.m.) ]/[ $\left[{ }^{14} \mathrm{C} /{ }^{3} \mathrm{H}\right.$ in liver fatty acid (in d.p.m.)] was also measured [being shown as ${ }^{14} \mathrm{C} /{ }^{3} \mathrm{H}$ (fat/liver)]. Values for these three parameters in untreated controls were, respectively, 3.1 and $7.7 \mu \mathrm{mol}$ of $\mathrm{C}_{2}$ units/h per $\mathrm{g}$ wet wt. tissue, and 9.5. Other details are in the text. Results are means \pm S.E.M. for the number of observations in parentheses.

\begin{tabular}{|c|c|c|c|}
\hline & $\begin{array}{l}\text { Time after } \\
\text { partial } \\
\text { hepatectomy } \\
\text { (days) }\end{array}$ & $\begin{array}{c}\text { Partial } \\
\text { hepatectomy }\end{array}$ & $\begin{array}{c}\text { Sham } \\
\text { operation }\end{array}$ \\
\hline $\begin{array}{l}\text { Hepatic cholesterol synthesis } \\
\left(\mu \mathrm{mol} \text { of } \mathrm{C}_{2} \text { units/h per } \mathrm{g}\right)\end{array}$ & $\begin{array}{l}2 \\
3 \\
4 \\
6\end{array}$ & $\begin{array}{l}5.02 \pm 1.49 \\
3.53 \pm 0.41 \\
3.39 \pm 0.68 \\
2.17 \pm 0.14\end{array}$ & $\begin{array}{l}4.21 \pm 0.27(3) \\
2.44 \pm 0.81(3) \\
3.12 \pm 0.41(4) \\
2.31 \pm 0.14(6)\end{array}$ \\
\hline Adipose-tissue fatty acid synthesis & 1 & - & $2.55 \pm 0.31(4)$ \\
\hline$\left(\mu \mathrm{mol}\right.$ of $\mathrm{C}_{2}$ units/h per $\left.\mathbf{g}\right)$ & $\begin{array}{l}2 \\
3 \\
4 \\
6\end{array}$ & $\begin{array}{l}1.70 \pm 0.54(10) \\
2.48 \pm 0.77 \\
2.94 \pm 0.85 \\
2.55 \pm 0.38\end{array}$ & $\begin{array}{l}2.09 \pm 0.46(8) \\
1.08 \pm 0.31(5) \\
2.94 \pm 1.32(4) \\
3.17 \pm 1.24(7)\end{array}$ \\
\hline Ratio ${ }^{14} \mathrm{C} /{ }^{3} \mathrm{H}$ (fat/liver) & $\begin{array}{l}2 \\
3 \\
6\end{array}$ & $\begin{array}{l}4.5 \pm 1.6 \\
5.0 \pm 0.3 \\
9.4 \pm 2.3\end{array}$ & $\begin{array}{l}4.0 \pm 0.6 \text { (9) } \\
5.9 \pm 3.1 \text { (3) } \\
7.1 \pm 1.9 \text { (4) }\end{array}$ \\
\hline
\end{tabular}

Synthesis of liver cholesterol and fatty acids in adipose tissue

It is possible that there is a requirement for extra synthesis of cholesterol during regeneration of the liver, so this was measured with ${ }^{3} \mathrm{H}_{2} \mathrm{O}$ (Table 4). During the first 4 days of regeneration, although a trend was noticeable towards greater cholesterol synthesis after partial hepatectomy (compared with rates in sham-operated controls), no major differences emerged. Also, no significant alteration in adipose-tissue fatty acid synthesis was observed in partially hepatectomized animals (Table 4) compared with sham-operated controls.

If animals receive both $\left[{ }^{14} \mathrm{C}\right]$ glucose and ${ }^{3} \mathrm{H}_{2} \mathrm{O}$, the quotient $\left[{ }^{14} \mathrm{C} /{ }^{3} \mathrm{H}\right.$ (in d.p.m.) in adipose tissue]/ $\left[{ }^{14} \mathrm{C} /{ }^{3} \mathrm{H}\right.$ (in d.p.m.) in liver] gives a measure of the relative significance of blood-borne glucose as a precursor of fatty acids in adipose tissue, compared with liver (Hems et al., 1975). This quotient was 4-9 in the present experiments (Table 4), showing that blood-borne glucose contributed at most $25 \%$ of the carbon of synthesized fatty acids in the liver. There were no differences between partially hepatectomized and sham-operated rats.

\section{Synthesis of fatty acids in the perfused liver}

To decide whether the accelerated fatty acid synthesis observed in the regenerating liver of the intact animal reflected an intrinsic alteration in the hepatic capacity for fatty acid synthesis, livers were perfused under controlled conditions (Table 5). Three sets of conditions were used, chosen because of the significance in regulation of hepatic fatty acid synthesis of the constituents added to the perfusate. In no case was the rate of fatty acid synthesis altered in perfused regenerating liver compared with that in controls (Table 5).

\section{Concentration of liver glycogen and plasma lipids}

Fatty acid synthesis in the liver is dependent on glycogen content (Salmon et al., 1974) and on circulating unesterified fatty acid concentration (Mayes \& Topping, 1974). To assess the importance of these factors after hepatectomy, liver glycogen (Fig. 2) and plasma unesterified fatty acids and triacylglycerols (Fig. 3) were measured. The glycogen content declined transiently after hepatectomy (Fig. 2), in agreement with other studies (Simek et al., 1968; Bonney et al., 1973). There were no major changes in the concentration of plasma unesterified fatty acids or triacylglycerols compared with shamoperated controls (Fig. 3).

\section{Activity of acetyl-CoA carboxylase in liver}

It is widely held that the major control site of fatty acid synthesis is the acetyl-CoA carboxylase reaction . (e.g. see review by Volpe \& Vagelos, 1976). Therefore this enzyme was assayed in regenerating liver (Table 6). No difference was found, compared with activities in sham-operated rats. Activities were of the same order as the rates of fatty acid synthesis (cf. Fig. 1 and Table 6).

Vol. 170 
Table 5. Fatty acid synthesis in perfused livers from rats after partial hepatectomy

Livers were perfused with bicarbonate-buffered saline (Krebs \& Henseleit, 1932) containing albumin, and washed rat erythrocytes; ${ }^{3} \mathrm{H}_{2} \mathrm{O}(10 \mathrm{mCi})$ and $\left[\mathrm{U}-{ }^{14} \mathrm{C}\right] \mathrm{glucose}(12 \mu \mathrm{Ci} ; 3 \mathrm{mCi} / \mathrm{mmol})$ were added after $30 \mathrm{~min}$ perfusion. The $\mathrm{C}_{3}$ substrates were added to perfusate as follows: initial lactate concentration was $10 \mathrm{~mm}$, and then a mixture of lactate, glycerol and pyruvate was infused (proportions $3: 2: 1$ respectively, total concentration $0.33 \mathrm{M}$, rate of infusion $3 \mathrm{ml} / \mathrm{h})$. Sodium oleate was added as a warm solution $(20 \mathrm{~mm}, \mathrm{pH}$ approx. 8.5$)$ to perfusion fluid containing albumin. At $1 \mathrm{~h}$ after addition of the labelled precursors, liver fatty acids were isolated and analysed. Other details are in the text. Results are means \pm S.E.M.

Fatty acid synthesis

( $\mu \mathrm{mol}$ of $\mathrm{C}_{2}$ units/h per $\mathrm{g}$ of fresh liver)

\begin{tabular}{|c|c|c|c|c|c|}
\hline \multirow[b]{3}{*}{$\begin{array}{l}\text { Substrates in } \\
\text { perfusate }\end{array}$} & \multirow[b]{3}{*}{$\begin{array}{l}\text { No. of } \\
\text { perfusions }\end{array}$} & \multirow{2}{*}{\multicolumn{2}{|c|}{ Partial hepatectomy }} & & \\
\hline & & & & \multicolumn{2}{|c|}{ Sham operation } \\
\hline & & Total & $\begin{array}{l}\text { From } \\
\text { glucose }\end{array}$ & Total & $\begin{array}{l}\text { From } \\
\text { glucose }\end{array}$ \\
\hline $\begin{array}{c}\text { Glucose }(30 \mathrm{~mm}) \\
\text { Glucose }(15 \mathrm{~mm}), \\
\text { lactate }(10 \mathrm{~mm}), \\
C_{3} \text { substrates }\end{array}$ & $\begin{array}{l}3 \\
3\end{array}$ & $\begin{array}{l}13.9 \pm 2.9 \\
12.8 \pm 5.2\end{array}$ & $\begin{array}{c}2.8 \pm 0.6 \\
0.11 \pm 0.05\end{array}$ & $\begin{array}{l}17.2 \pm 5.1 \\
19.0 \pm 1.5\end{array}$ & $\begin{array}{c}4.6 \pm 1.5 \\
0.16 \pm 0.02\end{array}$ \\
\hline $\begin{array}{l}\text { Glucose }(5 \mathrm{mM}) \\
\text { oleate }(0.5 \mathrm{mM})\end{array}$ & 4 & $3.2 \pm 0.5$ & - & $3.8 \pm 0.5$ & - \\
\hline
\end{tabular}

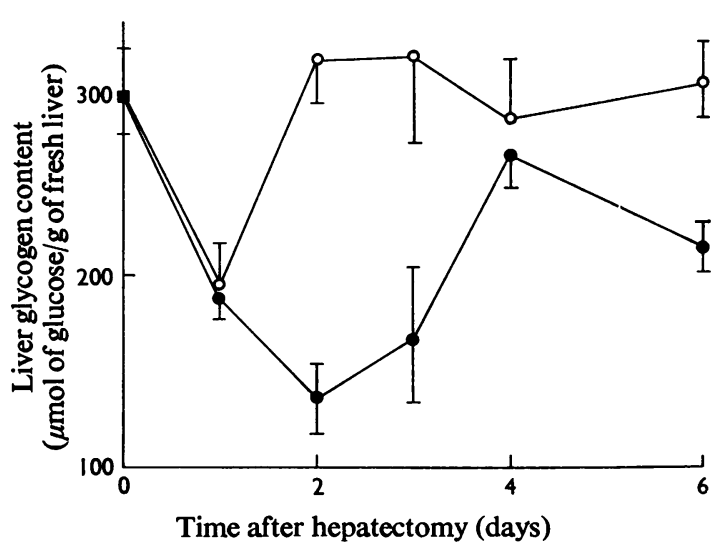

Fig. 2. Liver glycogen content in rats after partial hepatectomy

At various times after partial hepatectomy $(\bullet)$ or sham operation $(O)$, liver glycogen content was measured. Operations and sampling were at 10.00 $12.00 \mathrm{~h}$. The zero-time value $(\boldsymbol{\square})$ is given for nonoperated rats. Results are means \pm S.E.M. (the numbers of observations were the same as in Fig. 1). The glycogen content 2-3 days after hepatectomy is significantly different $(P<0.05)$ from control values.

\section{Discussion}

\section{Synthesis of lipids in regenerating liver}

During the period of hepatic growth after partial hepatectomy, there is a need for net synthesis of extra lipids. The present results demonstrate that this requirement is met at least partly by accelerated synthesis de novo of fatty acids within the liver. This

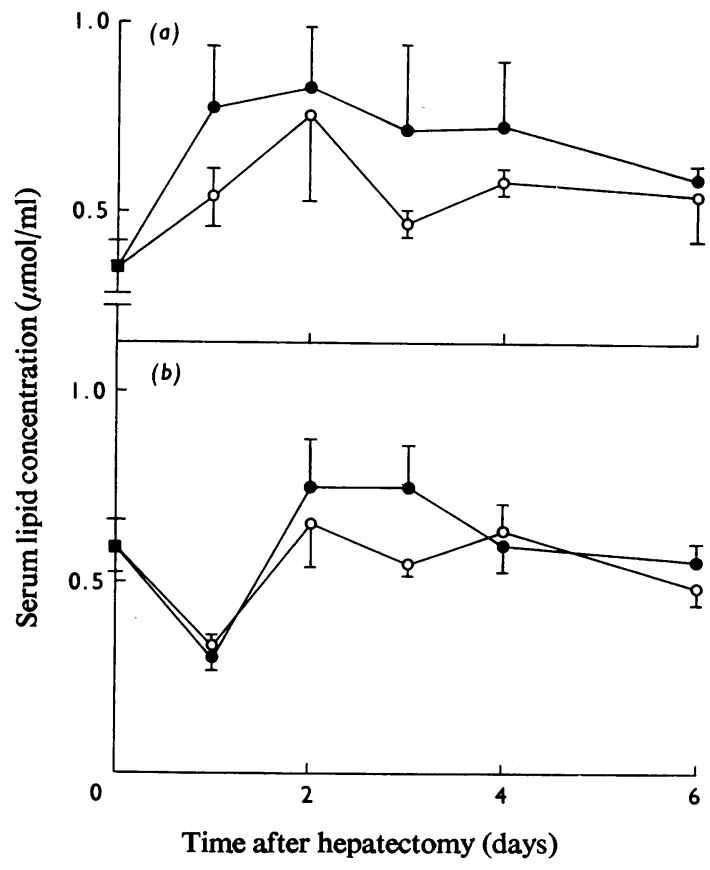

Fig. 3. Serum lipids in rats after partial hepatectomy At various times after partial hepatectomy $(\bullet)$ or sham operation $(O)$ rats were killed quickly by stunning and serum was prepared for determination of (a) total unesterified fatty acid, and (b) total triacylglycerol. The zero-time value ( $\square$ ) is given for nonoperated rats. Results are means \pm S.E.M. of three to six measurements.

increase could then complement the well-established enhancement of processes for conversion of longchain fatty acids into acylglycerols, to maintain the 
Table 6. Activity of acetyl-CoA carboxylase in the liver after partial hepatectomy

At 2 days after partial hepatectomy or sham operation the activity of acetyl-CoA carboxylase was assayed in the liver. Other details are given in the text. Results are means \pm S.E.M. for seven observations.

Acetyl-CoA carboxylase $(\mu \mathrm{mol} / \mathrm{min}$ per $\mathrm{g}$ of wet tissue)

$\begin{array}{lcc}\text { Assay conditions } & \begin{array}{c}\text { Partial } \\ \text { hepatectomy }\end{array} & \begin{array}{c}\text { Sham } \\ \text { operation }\end{array} \\ \text { Initial } & 0.29 \pm 0.02 & 0.22 \pm 0.02 \\ \text { Total } & 0.57 \pm 0.05 & 0.60 \pm 0.04\end{array}$

lipid content of hepatic membranes, fat-stores and lipoproteins (see the introduction for references).

The synthesis of both saturated long-chain fatty acids and monoenoic fatty acids was increased in regenerating liver. Hence this situation provides another instance where fatty acid mono-desaturation adapts in parallel with the total capacity for synthesis (Gellhorn \& Benjamin, 1966).

In the early phase of regeneration, a fatty liver is usually observed. In the present experiments, this feature persisted for 2 days. The increased rates of fatty acid synthesis could have contributed to the extra fat deposited (which consists entirely of triacylglycerol; Glende \& Morgan, 1968; the present work). The transient fatty nature of the liver is probably caused by the relative stress and fooddeprivation that occur for 1-2 days after partial hepatectomy (compared with either sham-operated controls or untreated animals), resulting in mobilization of fatty acids from adipose tissue to liver, rather than by any more subtle feature of the posthepatectomy state.

Cholesterol synthesis is not accelerated in the regenerating liver, presumably because a mammal always contains sufficient cholesterol to sustain turnover in the liver, during re-growth.

\section{Control of fatty acid synthesis in regenerating liver}

The enhanced capacity for fatty acid synthesis in the liver of rats after hepatectomy requires explanation. A group of possible non-specific causes may be excluded; thus the increased lipogenesis is unlikely to be a response to relative food deprivation (which was present in the hepatectomized rats, compared with sham-operated controls) or to their relative fall in liver glycogen content, or to any relative changes in plasma lipid concentrations (as no significant changes were observed in hepatectomized rats compared with sham-operated rats). Also, it is relevant that fatty acid synthesis in adipose tissue was not accelerated in partially hepatectomized compared with sham- operated rats. Non-specific influences (e.g. differences in stress or diet) would in general be expected to affect both tissues and to lead to a decrease in fatty acid synthesis (rather than enhancement) compared with the rate in untreated rats.

Therefore the enhancement of fatty acid synthesis in the regenerating liver may reflect a regulatory response which is specific to the re-growth situation. This response does not appear to involve intrinsic alterations in the hepatic capacity for lipogenesis, as was shown by perfused liver experiments, and by measurements of the maximum assayable activity of acetyl-CoA carboxylase (widely held to be the major regulatory site in fatty acid synthesis). Therefore the acceleration in fatty acid synthesis in the regenerating liver (in vivo) appears to be due to continuous action of intracellular or blood-borne modifiers (e.g. hormones or substrates). The relevant modifiers cannot include insulin or glucagon in plasma, whose concentrations are decreased and increased (respectively) after hepatectomy (Leffert et al., 1975; Morley et al., 1976), and these changes would not be expected to promote hepatic fatty acid synthesis.

We thank the Medical Research Council (U.K.) for a scholarship to C.D.G., and Dr. D. M. Salmon for carrying out the g.l.c. analysis of hepatic triacylglycerols.

\section{References}

Bartsch, G. G. \& Gerber, G. B. (1966) J. Lipid Res. 7, 204-209

Bergelson, L. D., Dyatlovitskaya, E. V., Sorkina, L. B. \& Gorkova, N. P. (1974) Biochim. Biophys. Acta 360, 361-365

Bonney, R. J., Hopkins, H. A., Walker, P. R. \& Potter, V. R. (1973) Biochem. J. 136, 115-124

Carlson, C. A. \& Kim, K.-H. (1974) Arch. Biochem. Biophys. 164, 490-501

Chen, T. C. (1967) J. Biol. Chem. 242, 173-181

Delahunty, T. J. \& Rubinstein, D. (1970) J. Lipid Res. 11, $536-543$

Fex, G. (1970a) Biochim. Biophys. Acta 202, 415-425

Fex, G. (1970b) Biochem. J. 119, 743-747

Fex, G. \& Olivecrona, T. (1968a) Biochim. Biophys. Acta $152,237-243$

Fex, G. \& Olivecrona, T. (1968b) Biochim. Biophys. Acta $164,424-426$

Fex, G. \& Thorzell, K. (1975) Lipids 10, 267-269

Gellhorn, A. \& Benjamin, W. (1966) Adv. Enzyme Regul. $4,19-41$

Girard, A., Roheim, P. S. \& Eder, H. A. (1971) Biochim. Biophys. Acta 248, 105-113

Glende, E. A. \& Morgan, W. S. (1968) Exp. Mol. Pathol. 8, 190-200

Halestrap, A. P. \& Denton, R. M. (1973) Biochem. J. 132, 509-517

Hems, D. A., Rath, E. A. \& Verrinder, T. R. (1975) Biochem. J. 150, 167-173

Vol. 170 
C. D. GOVE AND D. A. HEMS

Kirk, C. J., Verrinder, T. R. \& Hems, D. A. (1976) Biochem. J. 156, 593-602

Krebs, H. A. \& Henseleit, K. (1932) Hoppe-Seyler's Z. Physiol. Chem. 210, 33-66

Leffert, H., Alexander, N. M., Faloona, G., Rubalcava, B. \& Unger, R. (1975) Proc. Natl. Acad. Sci. U.S.A. 72, 4033-4036

Lowenstein, J. M. (1971) J. Biol. Chem. 246, 629-632

Mangiapane, E. H., Lloyd-Davies, K. \& Brindley, D. N. (1973) Biochem. J. 134, 103-112

Mayes, P. A. \& Topping, D. J. (1974) Biochem. J. 140,111114

Morley, C. G. D., Kuku, S., Rubinstein, A. H. \& Boyer, J. L. (1976) Biochem. Biophys. Res. Commun. 67, 653661

Neville, E. D., Talatico, K. S. \& Feller, D. D. (1970) Proc. Soc. Exp. Biol. Med. 134, 372-379
Olivecrona, T. \& Fex, G. (1970) Biochim. Biophys. Acta 202, 259-268

Salmon, D. M. W., \& Hems, D. A. (1973) Biochem. J. 136, 551-563

Salmon, D. M. W. \& Hems, D. A. (1976) Biochem. Soc. Trans. 4, 659-662

Salmon, D. M. W., Bowen, N. L. \& Hems, D. A. (1974) Biochem. J. 142, 611-618

Simek, J. F., Rubin, F. \& Lieberman, I. (1968) Biochem. Biophys. Res. Commun. 30, 571-575

Takeuchi, N., Katayama, Y., Matsumiya, Uchida, K. \& Yamamura, Y. (1976) Biochim. Biophys. Acta 450, 57-68

Tata, J. R. (1970) Biochem. J. 116, 617-630

Volpe, J. J. \& Vagelos, P. R. (1976) Physiol. Rev. 56, 339417

Windmueller, H. G. \& Spaeth, A. E. (1966) J. Biol. Chem. 241, 2891-2899 